\title{
Effect of Preoperative Dutasteride on Bleeding Related to Transurethral Resection of Prostate in Patients with Benign Prostatic Hyperplasia
}

\author{
Md. Mostafiger Rahman ${ }^{*}$, Fatema-Tuj Johura ${ }^{2}$, Md. Amanur Rasul ${ }^{3}$, \\ Abul Kalam Mohammed Musa Bhuiyan ${ }^{3}$, Mohammad Ibrahim Ali ${ }^{4}$, Md. Sazzad Hossain ${ }^{5}$, \\ Md. Kamrul Islam6, A. K. M. Shahidur Rahman7, Fahad Al Shatil Ashrafee ${ }^{7}$ \\ ${ }^{1}$ Department of Urology, Prime Medical College, Rangpur, Bangladesh \\ ${ }^{2}$ Department of Pharmacology, Prime Medical College, Rangpur, Bangladesh \\ ${ }^{3}$ Department of Urology, Dhaka Medical College, Dhaka, Bangladesh \\ ${ }^{4}$ Department of Urology, Dhaka Medical College Hospital (DMCH), Dhaka, Bangladesh \\ ${ }^{5}$ Apollo Hospital Ltd. Ghulsan, Dhaka, Bangladesh \\ ${ }^{6}$ Zilla-Sadar Hospital, Hobigong, Bangladesh \\ ${ }^{7}$ Department of Nephrology, Bangabandhu Sheikh Mujib Medical University (BSMMU), Dhaka, Bangladesh \\ Email: *mostafiger.bd@gmail.com
}

How to cite this paper: Rahman, M.Md., Johura, F.-T., Rasul, A.Md., Bhuiyan, A.K.M.M., Ali, M.I., Hossain, S.Md., Islam, K.Md., Rahman, A.K.M.S. and Al Shatil Ashrafee, F. (2019) Effect of Preoperative Dutasteride on Bleeding Related to Transurethral Resection of Prostate in Patients with Benign Prostatic Hyperplasia. Journal of Biosciences and Medicines, 7, 157-169. https://doi.org/10.4236/jbm.2019.75017

Received: April 6, 2019

Accepted: May 24, 2019

Published: May 27, 2019

Copyright ( 2019 by author(s) and Scientific Research Publishing Inc. This work is licensed under the Creative Commons Attribution International License (CC BY 4.0).

http://creativecommons.org/licenses/by/4.0/ c) (i) Open Access

\begin{abstract}
Background: Transurethral resection of prostate (TURP) is the gold standard in the surgical treatment of symptomatic benign prostatic hyperplasia (BPH). Blood loss is one of the most common complications of TURP. Objective: To evaluate the effect of preoperative dutasteride on bleeding related to TURP in patients with BPH. Materials and Methods: This prospective interventional study was done in the department of urology, Dhaka Medical College Hospital, Dhaka, Bangladesh during the period of July 2016 to June 2017. A total of 70 cases of BPH planned for TURP were included in this study according to the statistical calculation. Patients were randomly allocated to control group A (TURP without dutasteride) and dutasteride group B (TURP with dutasteride). Each group consisted of 35 patients. Group B patients were treated with dutasteride $0.5 \mathrm{mg} /$ day for 4 weeks before TURP. The main outcome of blood loss was evaluated in terms of reduction in serum hemoglobin $(\mathrm{Hb})$ and hematocrit (Hct) levels, which were measured before and 24 hours after surgery. Data were analyzed and compared by statistical tests. Results: Comparison of outcome between groups shows that there was a significant difference in term of pre-post operative change of hemoglobin and hematocrit levels in the control group A compared to the dutasteride group $\mathrm{B}(\mathrm{Hb}=2.96 \pm 0.80 \mathrm{gm} / \mathrm{dl} \mathrm{vs}$. $1.81 \pm 0.71 \mathrm{gm} / \mathrm{dl}$, respectively, $\mathrm{p}=0.001 ; \mathrm{Hct}=11.20 \% \pm 2.12 \%$ vs. $6.07 \% \pm$ $2.02 \%$, respectively, $\mathrm{p}=0.02$ ). A significant lower mean blood loss was ob-
\end{abstract}


served in the dutasteride group compared to the control group. Conclusion: Preoperative dutasteride therapy reduces blood loss related to TURP in patients with $\mathrm{BPH}$. This therapy can be practiced to reduce surgical bleeding associated with TURP.

\section{Keywords}

Benign Prostatic Hyperplasia (BPH), Dutasteride,

Transurethral Resection of Prostate (TURP)

\section{Introduction}

Benign prostatic hyperplasia $(\mathrm{BPH})$ is the most common urological problem. Patients with $\mathrm{BPH}$ who do not respond to medical treatment often undergo transurethral resection of the prostate (TURP), the gold standard for surgical treatment [1]. The safety and efficacy of TURP have been proven and validated [2]. Blood loss is one of the most important causes of morbidity during TURP. Haematuria and clot retention after TURP might increase the need for blood transfusion, prolong the hospital stay and even necessitate re-operation [3]. BPH is characterized by increased proliferation of stromal and acinar cells around the urethra and increased gland angiogenesis [4]. Five-alpha-reductase inhibitor (5ARI) dutasteride, block the conversion of testosterone to dihydrotestosterone (DHT) and reduces volume and angiogenesis in the prostate. This feature was used to prevent blood loss related to TURP. The efficacy of dutasteride in the treatment of gross hematuria associated with $\mathrm{BPH}$ is well established [5] [6] [7]. The thought behind the belief that 5ARI reduces blood loss during TURP is that these drugs shrink the prostate by reducing the number of blood vessels [4] [8] [9] [10]. Dutasteride reduces intraoperative TURP bleeding by reduction of microvessel density in hypertrophic prostatic tissue [11]. Several studies showed that preoperative treatment with dutasteride for two (2) weeks before TURP reduces the surgical bleeding [6] [10] [11] [12]. Treatment with dutaseride resulted in sustained and consistent DHT suppression, a continued reduction in total and transition zone prostate volume. Dutasteride decreased the serum concentration of DHT by $86 \%-89 \%$. It is well tolerated and effective in reducing intraprostatic DHT within 4 weeks [7]. Hagerty et al. [13] first reported that pretreatment with 5ARI appears useful in reducing perioperative bleeding in patients undergoing TURP. However, the ability of 5ARI to decrease blood loss during TURP for BPH remains controversial [14] [15]. Several studies demonstrated that preoperative dutasteride therapy could reduce bleeding and blood loss related complications of TURP [10] [16] [17]. But there is scarce evidence addressing the effect of preoperative dutasteride on bleeding related to TURP in patients with $\mathrm{BPH}$. The aim of this study was to evaluate the effect of preoperative dutasteride on bleeding related to TURP in patients with BPH. 


\section{Materials and Methods}

This prospective interventional study was carried out in the department of urology, Dhaka Medical College Hospital (DMCH), Dhaka, Bangladesh during the period of July 2016 to June 2017. This study was approved by the Ethical Review Committee, Dhaka Medical College, Dhaka, Bangladesh. Written informed consent was taken from every case. Each study subject was evaluated by history, physical examination and investigations. History was taken regarding lower urinary tract syndrome (LUTS), urinary tract infection, bronchial asthma, diabetes mellitus, hypertension, ischemic heart disease, any hematological disorders and any prostatic or urethral surgery. Physical examination included general examination, examination of the renal region and other parts of genitourinary system. All patients were investigated properly by-Urine for $\mathrm{R} / \mathrm{M} / \mathrm{E}$ and $\mathrm{C} / \mathrm{S}$ to identify urinary tract infection (UTI), if any infection detected that was treated according to antimicrobial sensitivity; Serum prostate-specific antigen (S. PSA) to exclude carcinoma of prostate; $S$. Creatinine to exclude renal insufficiency due to obstructive uropathy; S. Electrolyte to identify any electrolyte imbalance; Complete blood count (CBC) was done to see Hemoglobin (Hb) levels, Hematocrit (Hct) levels, Platelet counts, etc; Blood for Bleeding time (BT), Clotting Time (CT), Prothrombin time (PT) and Activated partial thromboplastin time (APTT) were done to see any coagulation disorder; Ultrasonogram of KUB with post void residue (PVR) was done to evaluate the size, volume and echo-texture of prostate and any hydronephrotic change or hydroureter or any other pathology in the KUB region; Uroflowmetry to see urinary flow rate.

A total of 70 cases of symptomatic BPH planned for TURP were selected. Patients with $\mathrm{BPH}$ who did not respond to medical therapy with an alpha-blocker, urinary refractory retention, chronic retention of urine and recurrent UTI were selected. Patients were excluded if they had chronic renal failure, any bleeding disorder, previous prostatic or urethral surgery, recurrent gross hematuria, bladder stones and evidence of prostate cancer. Patients who received any 5ARI (Finasteride or dutasteride) or aspirin or antiplatelet drugs before the study and had a previous hypersensitivity to dutasteride were also excluded. If serum prostate-specific antigen (S. PSA) levels were found high ( $>4 \mathrm{ng} / \mathrm{ml}$ ), transrectal ultrasound guided prostate biopsies were carried out before TURP.

Total seventy (70) patients were allocated. Among them, the control group A (TURP without dutasteride) consisted of 35 patients did not receive preoperative dutasteride and the dutasteride group B (TURP with dutasteride) consisted of 35 patients were treated with dutasteride $0.5 \mathrm{mg} /$ day for 4 weeks before TURP. All the odd-numbered cases were allocated for group A; the even-numbered cases were allocated for group B. Patients who had a perforation of the prostatic capsule during surgery were excluded from the study and the same allocation was replaced by the successive cases. There were no reported adverse events that considered to be drug-related.

TURP was done under a standard protocol of the operative procedure with spinal anesthesia in the dorsal lithotomy position. After urethrocystoscopy to see 
the anatomical landmark and morphology of enlarged prostate, urethral dilatation was done by Otis urethrotome up to $28 \mathrm{Fr}$. TURP was performed with a continuous flow $26 \mathrm{Fr}$. Resectoscope with $1.5 \%$ glycine irrigation fluid. Resection was started at 11 O'clock (right lobe) or 1 O'clock (left lobe) then gradually downwards up to the level of 6 O' clock position. After the completion of one lobe, another lateral lobe was resected in a similar fashion. If the median lobe ease enlarged, it was resected first to increase the flow of irrigation fluid. The depth of resection was extended as far as the prostatic capsule. After complete resection systemic hemostasis was undertaken, starting at bladder neck particularly from mucosal margin at 5 and 7 O'clock position. Then each lateral lobe was checked from 1 to 5 (clockwise, Left lobe) and 7 - 11 O'clock (counterclockwise, Right lobe). All chips of prostatic tissue were evacuated with Ellik's evacuator. Prostate volume was measured and sends for histopathological examination. The procedure was performed by the urologists. The surgeon was blind to each patient's profiles regarding preoperative dutasteride therapy to prevent a possible bias. Postoperative care carried out via an indwelling 20 Fr. Tri-channel foley's catheter with a $30 \mathrm{ml}$ urethral catheter balloon and continuous $0.9 \%$ normal saline bladder irrigation was done until the hematuria disappeared. During the postoperative period, both groups were compared with respect to clot retention, continuous bladder irrigation, and post-operative hospital stay. The patients had been discharged if they could void with clear urine. The outcome variables between groups were blood loss, indicated by the reduction in hemoglobin $(\mathrm{Hb})$ and hematocrit $(\mathrm{Hct})$ levels, which were estimated by measuring $\mathrm{Hb}$ and $\mathrm{Hct}$ values before surgery and 24 hours after surgery.

Data were processed and analyzed with the help of SPSS (Statistical package for social sciences) Version 22.0, Microsoft Excel version 15.31 and the internet. Statistical analysis was done with the "t" test, chi-square $\left(\chi^{2}\right)$ test and Fisher's exact test and the p-value of 0.05 considered as statistically significant.

\section{Results}

The present study intended to evaluate the effect of preoperative dutasteride therapy on bleeding related to TURP in patients with BPH. A total of 70 cases of $\mathrm{BPH}$ were allocated to group A (TURP without dutasteride) and group B (TURP with dutasteride). The main outcome variable between groups was blood loss in terms of reduction of pre-operative and post-operative hemoglobin $(\mathrm{Hb})$ and hematocrit (Hct) levels. Results of both groups were compiled and compared.

\subsection{Distribution of Age of the Patients}

The majority (around 54.28\%) of the patients in both the groups were in the age range 61 - 70 years. Out of 35 cases in each group, 51\% in Group-A and 57\% in Group-B were between 61 - 70 years of age. About 20\% in Group-A and 17\% in Group-B were between $\geq 50$ - 60 years. Only $28 \%$ in Group A and 25\% in Group $\mathrm{B}$ were found more than the age of 70 years. The groups were not statistically different in terms of age $(\mathrm{p}=0.7609)$ (Table 1$)$. 


\subsection{Prostatic Volume}

About $63 \%$ of the prostatic volume in both the groups were in range $61-80 \mathrm{gm}$. $31 \%$ in Group-A and 37\% in Group-B had a prostatic volume between $61-70$ gm. No significant difference was observed between groups in terms of prostatic volume $(62.96 \pm 10.03 \mathrm{gm}$ vs. $61.99 \pm 10.15, \mathrm{p}=0.69)($ Table 2$)$.

\subsection{Serum Prostate Specific Antigen (S. PSA)}

S. PSA level in total study patients (Mean \pm SD) was $3.19 \pm 1.43 \mathrm{ng} / \mathrm{ml}$ in Group-A and $3.20 \pm 1.96 \mathrm{ng} / \mathrm{ml}$ in Group-B. No significant difference was observed between the groups in terms of S. PSA level $(p=0.78)$ (Table 3$)$.

\subsection{Resected Prostatic Tissue}

About $45.72 \%$ in Group-A and $42.87 \%$ in Group-B had resected prostatic volume between 31 - $40 \mathrm{gm}$. No significant difference was observed between groups in terms of resected prostatic volume ( $33.36 \pm 9.01 \mathrm{gm}$ vs. $32.05 \pm 10.14 \mathrm{gm}, \mathrm{p}=0.78)$ (Table 4$)$.

Table 1. Distribution of patients according to age in groups.

\begin{tabular}{|c|c|c|c|}
\hline \multirow[b]{2}{*}{ Age } & \multicolumn{2}{|c|}{ Group } & \multirow[b]{2}{*}{ p-value } \\
\hline & $\begin{array}{c}\text { Group A } \\
\text { (TURP without dutasteride) } \\
(\mathrm{n}=35)\end{array}$ & $\begin{array}{c}\text { Group B } \\
\text { (TURP with dutasteride) } \\
(\mathrm{n}=35)\end{array}$ & \\
\hline$\geq 50-60$ & $07(20.00)$ & $06(17.14)$ & \\
\hline $61-70$ & $18(51.42)$ & $20(57.14)$ & \\
\hline$>70$ & $10(28.58)$ & 09 (25.72) & \\
\hline Total & $35(100.0)$ & $35(100.0)$ & \\
\hline Mean \pm SD & $65.22 \pm 5.61$ & $65.62 \pm 5.34$ & 0.7609 \\
\hline
\end{tabular}

Values in the parentheses denote the corresponding percentage. Data were analyzed using Student's t-Test and level of significance was $<0.05$.

Table 2. Distribution of patients according to the prostatic volume between the groups.

\begin{tabular}{|c|c|c|c|}
\hline \multirow[b]{2}{*}{ Prostatic Volume (gm) } & \multicolumn{2}{|c|}{ Group } & \multirow[b]{2}{*}{$\mathrm{p}$-value } \\
\hline & $\begin{array}{c}\text { Group A } \\
\text { (TURP without dutasteride) } \\
(\mathrm{n}=35)\end{array}$ & $\begin{array}{c}\text { Group B } \\
\text { (TURP with dutasteride) } \\
(\mathrm{n}=35)\end{array}$ & \\
\hline $41-50$ & $04(11.42)$ & $09(08.58)$ & \\
\hline $51-60$ & $09(25.72)$ & $10(28.58)$ & \\
\hline $61-70$ & $11(31.42)$ & $13(37.14)$ & \\
\hline $71-80$ & $11(31.42)$ & $09(25.71)$ & \\
\hline Total & $35(100.0)$ & $35(100.0)$ & \\
\hline Mean \pm SD & $62.96 \pm 10.03$ & $61.99 \pm 10.15$ & 0.6902 \\
\hline
\end{tabular}

Values in the parentheses denote the corresponding percentage. Data were analyzed using Student's t-Test and the level of significance was $<0.05$. 
Table 3. Distribution of patients according to S. PSA level between the groups.

\begin{tabular}{lccc}
\hline & \multicolumn{3}{c}{ Group } \\
\cline { 2 - 3 } S. PSA (ng/ml) & $\begin{array}{c}\text { Group A } \\
(\text { TURP without dutasteride) } \\
(\mathbf{n}=\mathbf{3 5})\end{array}$ & $\begin{array}{c}\text { Group B } \\
\text { (TURP with dutasteride) } \\
(\mathbf{n}=\mathbf{3 5})\end{array}$ & p-value \\
\hline Mean \pm SD & $3.19 \pm 1.43$ & $3.20 \pm 1.96$ & 0.7833 \\
\hline $\begin{array}{l}\text { Values are presented as Mean } \pm \text { SD. Data were analyzed using Student's t-Test and the level of significance } \\
\text { was }<0.05 .\end{array}$
\end{tabular}

Table 4. Comparison of resected prostatic tissue between the groups.

\begin{tabular}{|c|c|c|c|}
\hline \multirow[b]{2}{*}{$\begin{array}{l}\text { Resected Prostatic } \\
\text { Tissue (gm) }\end{array}$} & \multicolumn{2}{|c|}{ Group } & \multirow[b]{2}{*}{ p-value } \\
\hline & $\begin{array}{c}\text { Group A } \\
\text { (TURP without dutasteride) } \\
(\mathrm{n}=35)\end{array}$ & $\begin{array}{c}\text { Group B } \\
\text { (TURP with dutasteride) } \\
(\mathrm{n}=35)\end{array}$ & \\
\hline$\geq 10-20$ & $04(11.42)$ & $04(11.42)$ & \\
\hline $21-30$ & $06(17.14)$ & $08(22.86)$ & \\
\hline $31-40$ & $16(45.72)$ & $15(42.87)$ & \\
\hline $41-\geq 50$ & $09(25.72)$ & $08(22.86)$ & \\
\hline Total & $35(100.0)$ & $35(100.0)$ & \\
\hline Mean \pm SD & $33.36 \pm 9.01$ & $32.05 \pm 10.14$ & 0.782 \\
\hline
\end{tabular}

Values in the parentheses denote the corresponding percentage. Data were analyzed using Student's t-Test and the level of significance was $<0.05$.

\subsection{Operation Time}

Over $45 \%$ of the patients of Group-A required 61 - 90 minutes for the operation to be completed, while $60 \%$ of Group-B patients required 61 - 90 minutes for operation. The mean time required for operation was lower in the group $\mathrm{B}$ (74.62 \pm 16.01 minutes) than that in the group $\mathrm{A}(83.49 \pm 18.33$ minutes $)$ and the difference approaching the level of significance $(\mathrm{p}=0.0349)$ (Table 5).

\subsection{Pre-Operative Hemoglobin [(Hb) (gm/dl)] and Hematocrit [(Hct) (\%)]}

In group $\mathrm{A}$ and group $\mathrm{B}$, pre-operative $\mathrm{Hb}$ was $14.01 \pm 1.21 \mathrm{gm} / \mathrm{dL}$ and $13.95 \pm$ $1.23 \mathrm{gm} / \mathrm{dL}$, respectively. On the other hand, preoperative Hct was $43.50 \% \pm$ $3.11 \%$ and $43.04 \% \pm 3.24 \%$, respectively. No significant difference was observed (p-value $0.821 \& 0.549$ ) between the groups in terms of pre-operative hemoglobin (Hb) and hematocrit (Hct) levels (Table 6).

\subsection{Post-Operative Hemoglobin [(Hb) (gm/dl)] and Hematocrit [(Hct) (\%)]}

Postoperative $\mathrm{Hb}$ was $11.05 \pm 1.38$ and $12.13 \pm 1.30 \mathrm{gm} / \mathrm{dl}$ respectively in group A and group B. On the other hand postoperative Hct was $32.29 \% \pm 2.12 \%$ and $36.97 \% \pm 2.02 \%$ respectively between the groups. There was a significant differ- 
ence ( $\mathrm{p}$-value 0.012 and 0.001 ) between the groups in terms of postoperative hemoglobin and hematocrit levels (Table 7).

\subsection{Pre-Post Operative Change of Hemoglobin [(Hb) $(\mathrm{gm} / \mathrm{dl}]$ and Hematocrit [Hct (\%)]}

Mean difference of pre-postoperative change of $\mathrm{Hb}$ was $2.96 \pm 0.80$ and $1.81 \pm$ $0.71 \mathrm{gm} / \mathrm{dl}$ as well as Hct was $11.20 \% \pm 2.12 \%$ and $6.07 \% \pm 2.02 \%$ respectively in between group A and group B. Significant difference was observed (p-value 0.001 and 0.02 ) in term of pre-post operative change of hemoglobin and hematocrit levels in the dutasteride group compared to the control group (Table 8).

Table 5. Comparison of operation time ( $\mathrm{min})$ required between the groups.

\begin{tabular}{|c|c|c|c|}
\hline \multirow[b]{2}{*}{$\begin{array}{l}\text { Operation Time } \\
\qquad(\min )\end{array}$} & \multicolumn{2}{|c|}{ Group } & \multirow[b]{2}{*}{ p-value } \\
\hline & $\begin{array}{c}\text { Group A } \\
\text { (TURP without dutasteride) } \\
(\mathrm{n}=35)\end{array}$ & $\begin{array}{c}\text { Group B } \\
\text { (TURP with dutasteride) } \\
(\mathrm{n}=35)\end{array}$ & \\
\hline$<60$ & $06(17.14)$ & $07(20.00)$ & \\
\hline $61-90$ & $16(45.72)$ & $21(60.00)$ & \\
\hline$>90$ & $13(37.14)$ & $07(20.00)$ & \\
\hline Total & $35(100.0)$ & $35(100.0)$ & \\
\hline Mean \pm SD & $83.49 \pm 18.33$ & $74.62 \pm 16.01$ & 0.0349 \\
\hline
\end{tabular}

Values are represented as Mean \pm SD. Data were analyzed using Student's t-Test and the level of significance was $<0.05$.

Table 6. Distribution of patients according to pre-operative hemoglobin $(\mathrm{Hb})(\mathrm{gm} / \mathrm{dl})$ and hematocrit $(\mathrm{Hct})(\%)$ between groups.

\begin{tabular}{cccc}
\hline & \multicolumn{3}{c}{ Group } \\
$\begin{array}{c}\text { Pre-Operative } \\
\text { Hb \& Hct }\end{array}$ & \begin{tabular}{c} 
Group A \\
\cline { 2 - 3 }
\end{tabular} & $\begin{array}{c}\text { Group B } \\
\text { (TURP without dutasteride) } \\
(\mathbf{n}=35)\end{array}$ & $\begin{array}{c}\text { p-value } \\
\text { (TURP with dutasteride) } \\
(\mathbf{n}=35)\end{array}$ \\
\hline Pre-operative Hb & $14.01 \pm 1.21$ & $13.95 \pm 1.23$ & 0.821 \\
Pre-operative Hct & $43.50 \pm 3.11$ & $43.04 \pm 3.24$ & 0.549 \\
\hline
\end{tabular}

Values were represented as Mean \pm SD. Data were analyzed using Student's t-Test. The level of significance was $<0.05$.

Table 7. Distribution of patients according to post-operative $\mathrm{Hb}(\mathrm{gm} / \mathrm{dl})$ and Hct (\%) between groups.

\begin{tabular}{cccc}
\hline & \multicolumn{3}{c}{ Group } \\
Post-Oprative \\
\cline { 2 - 4 } Hb \& Hct & $\begin{array}{c}\text { Group A } \\
\text { (TURP without dutasteride) } \\
(\mathbf{n}=35)\end{array}$ & $\begin{array}{c}\text { Group B } \\
\text { (TURP with dutasteride) } \\
(\mathbf{n}=35)\end{array}$ & p-value \\
\hline Post-operative Hb & $11.05 \pm 1.38$ & $12.13 \pm 1.30$ & 0.012 \\
Post-operative Hct & $32.29 \pm 2.12$ & $36.97 \pm 2.02$ & 0.001 \\
\hline
\end{tabular}

Values were represented as Mean \pm SD. Data were analyzed using Student's t-Test. The level of significance was $<0.05$. 
Table 8. Comparison of pre-postoperative change of hemoglobin $[\mathrm{Hb}(\mathrm{gm} / \mathrm{dl})]$ \& hematocrit $[\mathrm{Hct}(\%)]$ between groups.

\begin{tabular}{cccc}
\hline \multirow{2}{*}{$\begin{array}{c}\text { Pre-Post Operative } \\
\text { Change of }\end{array}$} & \multicolumn{2}{c}{ Group } & \\
\cline { 2 - 3 } Hb \& Hct & $\begin{array}{c}\text { Group A } \\
\text { (TURP without dutasteride) } \\
(\mathrm{n}=35)\end{array}$ & $\begin{array}{c}\text { Group B } \\
\text { (TURP with dutasteride) } \\
(\mathrm{n}=35)\end{array}$ & p-value \\
\hline $\begin{array}{c}\text { Pre-postoperative } \\
\text { change Hb }\end{array}$ & $2.96 \pm 0.80$ & $1.81 \pm 0.71$ & 0.001 \\
$\begin{array}{c}\text { Pre-postoperative } \\
\text { change Hct }\end{array}$ & $11.20 \pm 2.12$ & $6.07 \pm 2.02$ & 0.02 \\
\hline
\end{tabular}

Values were represented as Mean \pm SD. Data were analyzed using Student's t-Test. The level of significance was $<0.05$.

Blood loss was evaluated in terms of reduction of preoperative and postoperative $\mathrm{Hb}(\mathrm{gm} / \mathrm{dl})$ and $\mathrm{Hct} \%$ level. There was a significant mean change of hemoglobin $(\mathrm{Hb})$ and hematocrit $(\mathrm{Hct})$ levels in the dutasteride group compared to the control group ( $\mathrm{p}=0.02$ vs. $\mathrm{p}=0.001$ ) (Figure 1 ).

\subsection{Irrigating Fluid Used (L) during TURP}

About $60 \%$ of Group-B cases required $>30 \mathrm{~L}$ irrigating fluid in TURP in comparison to $65.72 \%$ of Group $\mathrm{A}$. On the other hand $\leq 30 \mathrm{~L}$ irrigating fluid required in TURP, $34 \%$ in Group A and $40 \%$ in Group B. The difference was statistically significant $(\mathrm{p}=0.0074)$ (Table 9$)$.

\subsection{Continuous Bladder Irrigation (Day)}

Continuous bladder irrigation for more than 2 days was required in $48.58 \%$ in Group-B and $74.29 \%$ cases in Group A. On the other hand, less than 2 days was required in $51.42 \%$ in Group-B and $25.72 \%$ in Group A. The difference was statistically significant $(\mathrm{p}<0.007)$ (Table 10).

\subsection{Clot Retention}

Comparison between the groups shows that $8.57 \%$ in Group-A and $5.71 \%$ in Group-B developed clot retention. This difference was statistically not significant $(\mathrm{p}=0.479)($ Table 11).

\subsection{Postoperative Hospital Stay (Day)}

Comparison of hospital stay between groups demonstrated that $94.28 \%$ of the subjects of Group-B had stayed at the hospital for $\leq 3$ days following the TURP. In Group-A $82.86 \%$ had to stay at the hospital for $\leq 3$ days. The mean hospital stay was shorter in dutasteride group B $(2.69 \pm 0.58$ day) than control group A $(3.20 \pm 0.79$ day). This result was statistically significant $(p$-value $=0.003)($ Table 12$)$.

\section{Discussions}

For decades, transurethral resection of the prostate (TURP) has been the gold-standard therapy for symptomatic benign prostatic hyperplasia (BPH). 
Table 9. Comparison of irrigating fluid (L) used during TURP between the groups.

\begin{tabular}{cccc}
\hline & \multicolumn{3}{c}{ Group } \\
\cline { 2 - 3 } Irrigating & $\begin{array}{c}\text { Group A } \\
\text { Fluid (L) }\end{array}$ & $\begin{array}{c}\text { Group B } \\
(\mathrm{n}=35)\end{array}$ & p-value \\
& $12(34.20)$ & $14(40.00)$ & \\
$\leq 30$ & $23(65.72)$ & $21(60.00)$ & \\
$>30$ & $35(100)$ & $35(100)$ & \\
Total & $34.14 \pm 7.07$ & $29.83 \pm 5.60$ & 0.0074 \\
\hline
\end{tabular}

Values are represented as Mean \pm SD. Data were analyzed using Student's t-Test and the level of significance was $<0.05$.

Table 10. Comparison of continuous bladder irrigation (day) between groups.

\begin{tabular}{cccc}
\hline \multirow{2}{*}{$\begin{array}{c}\text { Duration of } \\
\text { Continuous } \\
\begin{array}{c}\text { Bladder Irrigation } \\
\text { (Day) }\end{array}\end{array}$} & $\begin{array}{c}\text { Group A } \\
\text { (TURP without dutasteride) } \\
(\mathbf{n}=\mathbf{3 5})\end{array}$ & $\begin{array}{c}\text { Group B } \\
\text { (TURP with dutasteride) } \\
(\mathbf{n}=\mathbf{3 5})\end{array}$ & p-value \\
\hline$\leq 2$ & $09(25.72)$ & $18(51.42)$ & \\
$>2$ & $26(74.29)$ & $17(48.58)$ & \\
Total & $35(100.0)$ & $35(100.0)$ & \\
Mean \pm SD & $2.92 \pm 0.52$ & $2.48 \pm 0.62$ & 0.007 \\
\hline
\end{tabular}

Values were represented as Mean \pm SD. Data were analyzed using Student's t-Test. The level of significance was $<0.05$.

Table 11. Comparison of clot retention between groups.

\begin{tabular}{cccc}
\hline & \multicolumn{2}{c}{ Group } & \\
\cline { 2 - 3 } Clot Retention & $\begin{array}{c}\text { Group A } \\
\text { (TURP without dutasteride) } \\
(\mathbf{n}=35)\end{array}$ & $\begin{array}{c}\text { Group A } \\
\text { (TURP without dutasteride) } \\
(\mathbf{n}=35)\end{array}$ & p-value \\
\hline Yes & $3(08.57)$ & $2(05.71)$ & \\
No & $32(91.43)$ & $33(94.29)$ & 0.479 \\
Total & $35(100.0)$ & $35(100.0)$ & \\
\hline
\end{tabular}

Values in the parentheses denote the corresponding percentage. Data were analyzed using Fisher's exact test. The level of significance was $<0.05$.

Table 12. Comparison of post-operative hospital stay (Day) between the groups.

\begin{tabular}{|c|c|c|c|}
\hline \multirow[b]{2}{*}{$\begin{array}{l}\text { Post-Operative } \\
\text { Hospital Stay } \\
\text { (Days) }\end{array}$} & \multicolumn{2}{|c|}{ Group } & \multirow[b]{2}{*}{ p-value } \\
\hline & $\begin{array}{c}\text { Group A } \\
\text { (TURP without dutasteride) } \\
(\mathrm{n}=35)\end{array}$ & $\begin{array}{c}\text { Group B } \\
\text { (TURP with dutasteride) } \\
(\mathrm{n}=35)\end{array}$ & \\
\hline$\leq 3$ & $29(82.86 \%)$ & $33(94.28 \%)$ & \\
\hline$>3$ & $06(17.14 \%)$ & $02(05.72 \%)$ & \\
\hline Total & $35(100.0)$ & $35(100.0)$ & \\
\hline Mean \pm SD & $3.20 \pm 0.79$ & $2.69 \pm 0.58$ & 0.003 \\
\hline
\end{tabular}

Values are represented as Mean \pm SD. Data was analyzed using Student's t-Test and the level of significance was $<0.05$. 


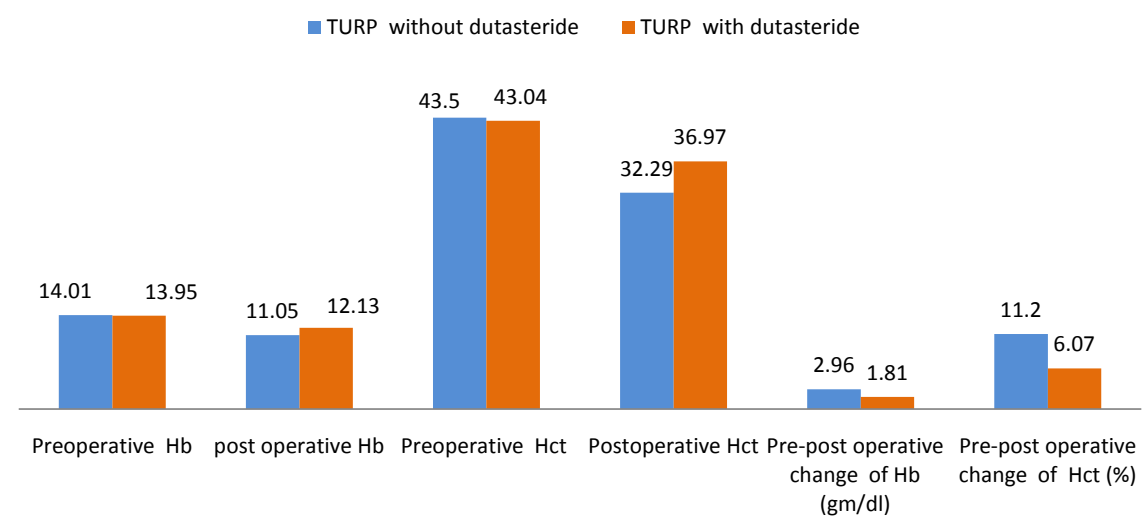

Figure 1. Bar diagram showing the comparison of the two groups with respect to preoperative and postoperative hemoglobin and hematocrit levels.

Perioperative blood loos is one of the most common complications of TURP. If it persists, it may necessitate blood transfusion and can lead to clot retention in the postoperative period. The efficacy of dutasteride in the treatment of gross hematuria associated with BEP is well established [5] [6] [7]. The scientific basis underlying dutasteride action in the reduction of hematuria of a prostatic origin is inhibition of angiogenic growth factors, thus decreasing prostate gland vascularization. This was shown by Donahue et al., after 2 weeks of 5 alpha-reductase inhibitor treatment [18]. Kravchick et al. showed that prostate gland vascularization was reduced after 6 weeks of dutasteride treatment [4]. The present study was undertaken to evaluate the effect of preoperative dutasteride therapy on blood loss related to TURP in patients with BPH.

A total of 70 Patients with BPH who were to undergo TURP, enrolled in this study by purposive sampling followed by inclusion and exclusion criteria. Patients allocated into two groups; the control group consisted of 35 patients did not receive preoperative dutasteride and the interventional (dutasteride) group consisted of 35 patients were treated with dutasteride $0.5 \mathrm{mg} / \mathrm{day}$ for 4 weeks before TURP. Blood loss was evaluated in terms of reduction in serum hemoglobin $(\mathrm{Hb})$ and hematocrit (Hct) levels, which were measured before surgery and 24 hours after surgery.

Martov et al. found a significant reduction in blood loss in patients by using dutasteride for at least one month before TURP compared to the control group [19]. Kravchick et al. demonstrated that six weeks of treatment with dutasteride reduced prostatic vascularity [4], especially in the periurethral area. Hahn et al. used dutasteride for 2 - 4 weeks before TURP and observed no significant reduction in blood loss compared to the placebo group [7]. Boccon-Gibod et al., Shanmugasundaram et al., and Pastore et al. reported that short-term treatment with dutasteride was not superior compared to the control group in decreasing TURP related blood loss, and suggested that a longer duration treatment will reduce intraoperative and postoperative bleeding [12] [15] [20]. In the present study, the difference between preoperative hemoglobin and hematocrit levels between the two groups were not statistically significant. But, there were signifi- 
cant differences in postoperative hemoglobin and hematocrit levels between the two groups. Kyu Shik Kim et al. and Pastore et al. showed similar results to the present study [2] [20]. In the current study, there was a significant difference in terms of pre-postoperative hemoglobin and hematocrit levels in the dutasteride group compared to the control group. Blood loss, indicated by the reduction in hemoglobin $(\mathrm{Hb})$ and hematocrit $(\mathrm{Hct})$ levels, was estimated by measuring $\mathrm{Hb}$ and Hct values before surgery and 24 hours after surgery. There was significant lower mean blood loss was observed in the dutasteride group compared to the control group. Kyu Shik Kim et al. reported that $\mathrm{Hb}$ and Hct declined less dutasteride group than in controls one day after surgery [2]. It has been documented that perioperative and postoperative bleeding was significantly reduced in the group taking dutasteride for 2 weeks before TURP [2]. Pastore et al. reported that there was a significantly lower mean blood loss in the dutasteride group compared to the control group [20]. Kravchick et al. found that the vascularity of the prostate, especially in the periurethral area, was reduced after taking dutasteride for six weeks [4]. This result seems to be sufficient to establish reduced prostatic vascularity in patients taking dutasteride. The most practical way to quantify blood loss during TURP is by a decrease in serum hemoglobin. Hematocrit was also estimated along with hemoglobin to overcome the effect of hydration. It may be difficult to quantify blood loss during TURP by measuring $\mathrm{Hb}$ in the irrigating fluid; however irrigating fluid $\mathrm{Hb}$ levels are only $5 \%-10 \%$ of that found in whole blood. Shanmugasundaram et al. [12] found a significant reduction in blood loss when dutasteride was taken for over a month before surgery. Blood loss was measured from irrigation fluid drained using HemoCue low hemoglobin system-photometer.

Hahn et al. found that 2 to 4 weeks pretreatment with dutasteride did not significantly reduce blood loss in TURP [7]. Arratia-Maqueo et al. [21] also demonstrated that dutasteride has no significant impact on blood loss during TURP. In the present study, clot retention was not statistically significant. Pastore et al., reported only two (2.85\%) cases required new catheterization for clot retention [20]. In this study, the duration of continuous bladder irrigation was statistically significant $(\mathrm{p}<0.007)$. Kyu Shik Kim et al. showed a significant difference in terms of continuous bladder irrigation between dutasteride \& control group $(1.81 \pm 1.08$ vs. $2.36 \pm 1.06, p=0.02)$ [2]. In this study, the mean hospital stay was shorter in dutasteride group B (2.69 \pm 0.58 day) than control group A (3.20 \pm 0.79 day) (p-value $=0.003)$. Kyu Shik Kim et al. showed that, treatment with dutasteride before TURP reduces surgical bleeding and length of hospitalization after TURP [2]. Several studies [4] [18] [19] found a significant reduction in blood loss in patients by using dutasteride for at least one month before TURP compared to the control group. In this study, preoperative dutasteride reduced blood loss in terms of pre-postoperative change of hemoglobin and hematocrit levels in the dutasteride group compared to the control group. A longer period of taking dutasteride should be compared with short-term treatment in terms of effects on blood loss. A large multicentre comparative study is required for fur- 
ther evaluation.

\section{Conclusion}

Preoperative dutasteride therapy reduces blood loss related to TURP in patients with $\mathrm{BPH}$. This therapy can be practiced to reduce surgical bleeding associated with TURP.

\section{Limitation}

It was a single center study with relatively small sample size. All complications of TURP were not included in the study. Moreover surgeon's heterogeneity was the mentionable limitation of this study.

\section{Conflicts of Interest}

The authors declare no conflicts of interest regarding the publication of this paper.

\section{References}

[1] Rassweiler, J., Teber, D., Kuntz, R. and Hofmann, R. (2005) Complications of Transurethral Resection of the Prostate (TURP) - Incidence, Management, and Prevention. European Urology, 50, 969-980.

https://doi.org/10.1016/j.eururo.2005.12.042

[2] Kim, K.S., Jeong, W.S., Sung, Y.P., Yong, T.K. and Hong S.M. (2015) The Effect of Two Weeks of Treatment with Dutasteride on Bleeding after Transurethral Resection of the Prostate. The World Journal of Men's Health, 33, 14-19. https://doi.org/10.5534/wjmh.2015.33.1.14

[3] Jamal, A., Nivasarao, P.S., Rajan, L.R. and Kumar. S. (2016) Is Transurethral Resection of Prostate Made Safer by Preoperative Dutasteride Therapy? A Randomized Controlled Trial. International Journal of Contemporary Medical Research, 3 , 43-50.

[4] Kravchick, S., Cytron, S., Mamonov, A., Peled, R. and Linov, L. (2009) Effect of Short-Term Dutasteride Therapy on Prostate Vascularity in Patients with Benign Prostatic Hyperplasia: A Pilot Study. Urology, 73, 1274-1278.

https://doi.org/10.1016/j.urology.2008.08.461

[5] Miller, J. and Tarter, T.H. (2007) Update on the Use of Dutasteride in the Management of Benign Prostatic Hypertrophy. Clinical Interventions in Aging, 2, 99-104.

[6] Zong, H.T., Peng, X.X., Yang, C.C. and Zhang, Y. (2011) A Systematic Review of the Effects and Mechanisms of Preoperative $5 \alpha$-Reductase Inhibitors on Intraoperative Hemorrhage during Surgery for Benign Prostatic Hyperplasia. Asian Journal of Andrology, 13, 812-818. https://doi.org/10.1038/aja.2011.86

[7] Hahn, R.G., Fagerström, T., Tammela, T.L., Trip, O.V. and Beisland, H.O. (2007) Blood Loss and Postoperative Complications Associated with Transurethral Resection of the Prostate after Pretreatment with Dutasteride. BJU International, 99, 587-594. https://doi.org/10.1111/j.1464-410X.2006.06619.x

[8] Gökçe, M.İ., Kerimov, S., Akıncı, A., Hamidi, N., Afandiyev, F. and Yaman, Ö. (2015) Effect of Dutasteride Treatment on Reducing Blood Loss and in the Perioperative Period of Open Prostatectomy. Turkish Journal of Urology, 41, 24-26. https://doi.org/10.5152/tud.2015.90094 
[9] Ren, J., Shi, C.L., Zhao, Q.J., et al. (2016) A Systematic Review and Meta-Analysis of the Effects on Dutasteride Treatment for Reducing Surgical Blood Loss during Transurethral Resection of the Prostate. Urologia Internationalis, 98, 456-465. https://doi.org/10.1159/000453669

[10] Zhu, Y.P., Dai, B., Zhang, H.L., Shi, G. and Ye, D.W. (2015) Impact of Preoperative $5 \alpha$-Reductase Inhibitors on Perioperative Blood Loss in Patients with Benign Prostatic Hyperplasia: A Meta-Analysis of Randomized Controlled Trials. BMC Urology, 15, Article ID: 2204. https://doi.org/10.1186/s12894-015-0043-4

[11] Zaitsu, M., Tonooka, A., Mikami, K., Hattori, M., Takeshima, Y. and Uekusa, T. (2013) A Dual $5 \alpha$-Reductase Inhibitor Dutasteride Caused Reductions in Vascular Density and Area in Benign Prostatic Hyperplasia. ISRN Urology, 2013, Article ID: 863489. https://doi.org/10.1155/2013/863489

[12] Shanmugasundaram, R., Singh, J.C. and Kekre, N.S. (2007) Does Dutasteride Reduce Perioperative Blood Loss and Postoperative Complications after Transurethral Resection of the Prostate? Indian Journal of Urology, 23, 334-335.

[13] Hagerty, J.A., Ginsberg, P.C., Harmon, J.D. and Harkaway, R.C. (2000) Pretreatment with Finasteride Decreases Perioperative Bleeding Associated with Transurethral Resection of Prostate. Urology, 55, 684-689.

https://doi.org/10.1016/S0090-4295(00)00454-4

[14] American Urological Association (2010) Guideline on the Management of Benign Prostatic Hyperplasia (BPH). American Urological Association Education and Research, Inc.

[15] Boccon-Gibod, L., Valton, M., Ibrahim, H. and Comenducci, A. (2005) Effect of Dutasteride on the Reduction of Intraoperative Bleeding Related to Transurethral Resection of Prostate. Progrès en Urologie, 15, 1085-1089.

[16] Busetto, G.M., Gabriele, A., Riccardo, G. (2013) 1601 Dutasteride Can Reduce Intraoperative Bleeding During Transurethral Resection of the Prostate: Evaluation of Vascular Endothelial Growth Factor (VEGF) and CD34. The Journal of Urology, 189, 658. https://doi.org/10.1016/j.juro.2013.02.3151

[17] Moon, H.S., Choi, H.Y., Park, H.Y. and Kim, Y.T. (2013) Effect of Treatment with Dutasteride on Transurethral Resection of the Prostate. https://www.ics.org

[18] Donohue, J.F., Hayne, D., Karnik, U., Thomas, D.R. and Foster, M.C. (2005) Randomized, Placebo-Controlled Trial Showing that Finasteride Reduces Prostatic Vascularity Rapidly within 2 Weeks. BJU International, 96, 1319-1322. https://doi.org/10.1111/j.1464-410X.2005.05849.x

[19] Martov, A.G. and Ergacov, D.V. (2008) The Experience in Dutasteride Use before Transurethral Prostatic Resection for Large Adenoma. Urologiia, 46, 48-52.

[20] Pastore, A.L., Mariani, S., Barrese, F., Palleschi, G., Valentini, A.M., Pacini, L., et al. (2013) Transurethral Resection of Prostate and the Role of Pharmacological Treatment with Dutasteride in Decreasing Surgical Blood Loss. Journal of Endourology, 27, 68-70. https://doi.org/10.1089/end.2012.0231

[21] Arratia-Maqueo, J.A., Garza-Cortés, R., Gómez-Guerra L.S. and Cortés-González J.R. (2010) Effect of One Month Treatment with Dutasteride on Transurethral Resection of the Prostate. Actas Urológicas Españolas, 34, 866-869.

https://doi.org/10.1016/j.acuro.2010.06.005 